\title{
Factors controlling the geochemical composition of Limnopolar Lake sediments (Byers Peninsula, Livingston Island, South Shetland Island, Antarctica) during the last ca. 1600 years
}

\author{
A. Martínez Cortizas ${ }^{1}$, I. Rozas Muñiz ${ }^{1}$, T. Taboada ${ }^{1}$, M. Toro ${ }^{2}$, I. Granados ${ }^{3}$, S. Giralt ${ }^{4}$, and S. Pla-Rabés ${ }^{5,6}$ \\ ${ }^{1}$ Departamento de Edafoloxía e Química Agrícola, Facultade de Bioloxía, Campus Vida s/n, \\ 15782 Santiago de Compostela, Spain \\ ${ }^{2}$ Centro de Estudios Hidrográficos (CEDEX), Paseo Bajo Virgen del Puerto, 3, 28005 Madrid, Spain \\ ${ }^{3}$ Centro de Investigación, Seguimiento y Evaluación, Parque Nacional de la Sierra de Guadarrama, Ctra. M-604. km 27.6, \\ 28740 Rascafría, Spain \\ ${ }^{4}$ Institute of Earth Sciences Jaume Almera (CSIC), Lluís Solé i Sabarís s/n, 08028 Barcelona, Spain \\ ${ }^{5}$ Centre for Ecological Research and Forestry Applications (CREAF), Campus UAB, Edifici C, 08193 Cerdanyola del Vallès, \\ Catalonia, Spain \\ ${ }^{6}$ Centre for Advanced Studies of Blanes (CEAB), Spanish Research Council (CSIC), Accés Cala St Francesc 14, \\ 17300 Blanes, Catalonia, Spain
}

Correspondence to: A. Martínez Cortizas (antonio.martinez.cortizas@usc.es)

Received: 31 January 2014 - Published in Solid Earth Discuss.: 11 March 2014

Revised: 3 June 2014 - Accepted: 4 June 2014 - Published: 10 July 2014

\begin{abstract}
We sampled a short $(57 \mathrm{~cm})$ sediment core in Limnopolar Lake (Byers Peninsula, Livingston Island, South Shetland Islands), which spans the last ca. 1600 years. The core was sectioned at high resolution and analyzed for elemental and mineralogical composition, and scanning electron microscope and energy dispersive X-ray spectrometer (SEM-EDS) analysis of glass mineral particles in selected samples. The chemical record was characterized by a contrasted pattern of layers with high $\mathrm{Ca}, \mathrm{Ti}, \mathrm{Zr}$, and $\mathrm{Sr}$ concentrations and layers with higher concentrations of $\mathrm{K}$ and $\mathrm{Rb}$. The former were also enriched in plagioclase and, occasionally, in zeolites, while the latter were relatively enriched in 2:1 phyllosilicates and quartz. This was interpreted as reflecting the abundance of volcaniclastic material (Ca rich) versus Jurassic-Lower Cretaceous marine sediments (K rich) - the dominant geological material in the lake catchment. SEM-EDS analysis revealed the presence of abundant volcanic shards in the Ca-rich layers, pointing to tephras most probably related to the activity of Deception Island volcano (located $30 \mathrm{~km}$ to the SE). The ages of four main peaks of volcanic-rich material (AD ca. 1840-1860 for L1, AD ca. 1570-1650 for L2, AD ca. 1450-1470 for L3,
\end{abstract}

and AD ca. 1300 for L4) matched reasonably well the age of tephra layers (AP1 to AP3) previously identified in lakes of Byers Peninsula. Some of the analyzed metals (Fe, $\mathrm{Mn}, \mathrm{Cu}$, and $\mathrm{Cr}$ ) showed enrichments in the most recent tephra layer (L1), suggesting relative changes in the composition of the tephras as found in previous investigations. No evidence of significant human impact on the cycles of most trace metals $(\mathrm{Cu}, \mathrm{Zn}, \mathrm{Pb})$ was found, probably due to the remote location of Livingston Island and the modest research infrastructures; local contamination was found by other researchers in soils, waters and marine sediments on areas with large, permanent research stations. Chromium is the only metal showing a steady enrichment in the last 200 years, but this cannot be directly attributed to anthropogenic pollution since recent research supports the interpretation that climatic variability (reduced moisture content and increased wind intensity) may have resulted in enhanced fluxes of mineral dust and trace elements ( $\mathrm{Cr}$ among them) to Antarctica. At the same time, some features of the chemical record suggest that climate may have also played a role in the cycling of the elements, but further research is needed to identify the underlying mechanisms. 


\section{Introduction}

In view of its location and remoteness Antarctica is a highly sensitive area to global change. Of particular concern are the effects of global warming because of the rapid responses that ecosystems may undergo in circumpolar areas, and because of the mounting evidence of recent major changes in polar regions (Pienitz et al., 2004; Convey et al., 2009). But to put present global change into context there is a need for long-term records of environmental changes. For this purpose, lake sediments are amongst the most used archives as they host a suite of abiotic (elemental composition, isotopic records, mineral composition, etc.) and biotic (pollen, testate amoebas, diatoms, charcoal, organic compounds, etc.) proxies which can potentially shed light on environmental changes (see for example Smol and Last, 2001; Smol et al., 2001a, b).

In contrast to the Arctic and temperate zones, fewer studies have used sediment cores from lakes in Antarctica (Muir and Rose, 2004) to track environmental change, despite the large abundance of lakes in some areas like Byers Peninsula (Livingston Island, South Shetland Islands) (Toro et al., 2007). Most of the investigations are based on sedimentological, elemental, and mineralogical analyses (Aceto et al., 1994; Bishop et al., 1996; Doran et al., 2000; Abollino et al., 2004; Webster-Brown and Webster, 2007; Malandrino et al., 2009), but also on the isotopic $\left(\delta^{13} \mathrm{C}, \delta^{15} \mathrm{~N}, \delta^{34} \mathrm{~S}\right) \mathrm{com}$ position (Bishop et al., 2001), or the content of organic pigments (Squier et al., 2005) of the sediments. The aim was to investigate the geochemistry of the lakes and to reconstruct climate changes. The identification and characterization of tephra layers also has received much attention (Björck et al., 1991; Björck and Zale, 1996b; Hodgson et al., 1998), pursuing the identification of their sources and to establish a tephrochronology for the Antarctic Peninsula. Of particular interest for our study is the chronostratigraphic investigation made by Toro et al. (2013) on a composite core sampled in Limnopolar Lake.

A second major line of research is that oriented to the reconstruction of pollution. It includes the determination, in lake sediments, of the concentrations of organic pollutants (Sarkar et al., 1994; Fuoco et al., 1996), trace metals (Yin et al., 2006; Bargagli et al., 2007), and spheroidal (fly ash) particles (Rose et al., 2012). These investigations demonstrate that the level of contamination in Antarctica is much lower than in the polar regions of the Northern Hemisphere. Despite the long-range transport of some contaminants (i.e. $\mathrm{Pb}$, $\mathrm{Hg}$, or organic pollutants) most of the impacts due to human activities are local (Tin et al., 2009) and mainly related to the presence of large, permanent research infrastructures (Claridge et al., 1995; Crockett, 1998; Sheppard et al., 2000; Crockett and White, 2003; Webster et al., 2003; Santos et al., 2006; Chaparro et al., 2007).

In this paper we present the results of a study on a short sediment core sampled in Limnopolar Lake in 2003. The ob- jective of our research was to perform a detailed (i.e. highresolution) investigation of the geochemistry of the lake sediments, with a combination of X-ray fluorescence (XRF), Xray diffraction (XRD), and scanning electron microscope and energy dispersive X-ray spectrometer (SEM-EDS) analyses, supported by age dating and multivariate statistics, with the aim of identifying the main factors involved in the observed chemical-mineralogical changes and their timing during the last ca. 1600 years.

\section{Material and methods}

\subsection{Study area}

Limnopolar Lake $\left(62^{\circ} 38^{\prime} 15^{\prime \prime} \mathrm{S}, 61^{\circ} 06^{\prime} 30^{\prime \prime} \mathrm{W}\right)$ is located in Byers Peninsula, the westernmost part of Livingston Island (South Shetland Islands, Fig. 1) and designated at present as an Antarctic Specially Protected Area (ASPA No. 6), limiting human presence in the past 46 years to scientific activities, keeping it free of human impacts, far from any Antarctic Base (Benayas et al., 2013). Livingston Island hosts modest research infrastructures: a non-permanent research camp in Byers Peninsula since 2001, located $1700 \mathrm{~m}$ away from Limnopolar Lake and used for periods of 1-3 months each year, and the Spanish and Bulgarian Antarctic Bases Juan Carlos I and St. Kliment Ohridski, located about $30 \mathrm{~km}$ to the east, since 1988 .

Climate is less extreme than in continental Antarctica, characterized by a high interannual variability of temperature and precipitation (annual mean values of $700-1000 \mathrm{~mm}$ ), with summer temperatures mostly above $0{ }^{\circ} \mathrm{C}$ (mean range from $1-3^{\circ} \mathrm{C}$ ) and frequent liquid water precipitation, and winter colder than $0{ }^{\circ} \mathrm{C}$ with a record low of $-27^{\circ} \mathrm{C}$ (Rochera et al., 2010; Bañón et al., 2013). The region is snow covered for at least eight months of the year, and the snow cover distribution and depth is dominated by topographic variables related to wind (Fassnacht et al., 2013). In the lake catchment there is a permafrost table below an active layer of thickness up to $90-130 \mathrm{~cm}$, with a thawing season of about 75 days between late December to late February (De Pablo et al., 2013).

This peninsula is the largest ice-free area of Maritime Antarctica, and contains a large number of lakes (Toro et al., 2007). Limnopolar Lake catchment has a surface area of $0.58 \mathrm{~km}^{2}$ and a water body area of $0.022 \mathrm{~km}^{2}$. The lake is ultra-oligotrophic and it is ice covered except for 2-3 months during the summer. Although it has a main inlet, surface runoff significantly contributes to the lake volume during snow pack melt and the period of thawing of the active layer of permafrost. The lake bottom is covered by a patchy carpet of the moss Drepanocladus longifolius (Mitt.) Paris (Toro et al., 2013).

Vegetation in the catchment is only composed of scattered patches of mosses, lichens, and microbial mats (Velázquez 


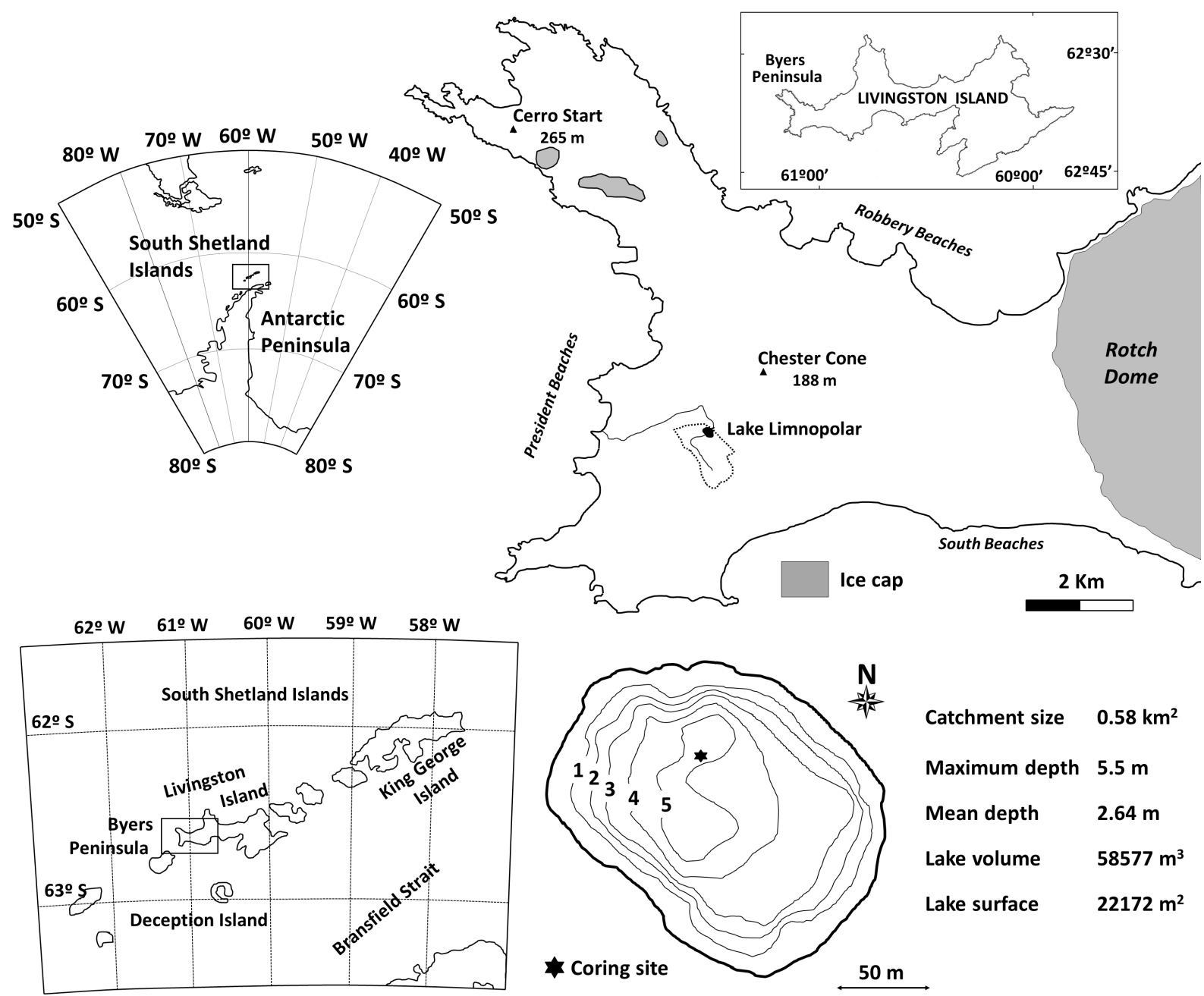

Figure 1. Location of Limnopolar Lake on Livingston Island (South Shetland Islands, Antarctica). Modified from Toro et al. (2013).

et al., 2013). The superficial formations are represented by a lithosol originating from the fragmentation of periglacial processes, weathering, and erosion of Upper Jurassic-Lower Cretaceous marine sediments, volcanic and volcaniclastic rocks (López- Martínez et al., 1996).

\subsection{Sediment sampling}

The LIM03/1 sediment core was collected in December 2003 using a Glew-type gravity corer at the deepest part of the lake (5.5 m, Fig. 1) when it was iced covered, retrieving the uppermost $57 \mathrm{~cm}$ of its sedimentary infill. It showed a centimetre to millimetre alternation of light brownish massive clays and silty clay layers, and dark brownish moss layers. A number of more discrete, millimetre-centimetre scale darker, silty layers, made up of volcanic material, were also found.

The core was sectioned (in situ) into $0.2 \mathrm{~cm}$ slices for the upper $10 \mathrm{~cm}$, and $0.5 \mathrm{~cm}$ slices below this depth. Samples were transferred to Whirl-Pak ${ }^{\circledR}$ bags, sealed, and stored in darkness at low temperature $\left(4{ }^{\circ} \mathrm{C}\right)$ until analysis. To opti- mize analytical effort and time, we selected 57 representative samples covering the whole core and keeping a reasonably good chronological resolution.

\subsection{Elemental and mineralogical analyses}

Before analysis, sub-samples were dried at $105^{\circ} \mathrm{C}$ until constant weight, finely milled and homogenized. The elemental composition ( $\mathrm{Si}, \mathrm{Al}, \mathrm{Fe}, \mathrm{Ti}, \mathrm{Ca}, \mathrm{K}, \mathrm{Mn}, \mathrm{Rb}, \mathrm{Sr}, \mathrm{Zr}, \mathrm{Cr}, \mathrm{Cu}$, $\mathrm{Zn}$, and $\mathrm{Pb}$ ) of the sediment was determined by $\mathrm{X}$-ray fluorescence dispersive EMMA-XRF analysis (Cheburkin and Shotyk, 1996, 1999; Weiss et al., 1998). Standard reference materials were used for the calibration of the instruments. Quantification limits were $10 \mathrm{~g} \mathrm{~kg}^{-1}$ for $\mathrm{Si}, \mathrm{Al}, \mathrm{Fe}$, and $\mathrm{Ti}$, $4 \mathrm{~g} \mathrm{~kg}^{-1}$ for $\mathrm{Ca}$ and $\mathrm{K}, 30 \mu \mathrm{g} \mathrm{g}^{-1}$ for $\mathrm{Mn}, 10 \mu \mathrm{g} \mathrm{g}^{-1}$ for $\mathrm{Cu}$, $5 \mu \mathrm{g} \mathrm{g}^{-1}$ for $\mathrm{Zn}, 2 \mu \mathrm{g} \mathrm{g}^{-1}$ for $\mathrm{Cr}, 1 \mu \mathrm{g} \mathrm{g}^{-1}$ for $\mathrm{Rb}, \mathrm{Sr}$, and $\mathrm{Zr}$, and $0.5 \mu \mathrm{g} \mathrm{g}^{-1}$ for $\mathrm{Pb}$. Reproducibility was assessed by replicate measurements every three samples; all replicates agreed within a $5 \%$. 
The mineralogical composition was determined by X-ray diffraction using a Philips PW1710 diffractometer (CuK $\alpha$ radiation and graphite monochromator). Quantification of the mineral phases was done using Match! 1.11e software.

Five dried, but otherwise unmodified, sediment samples, from $30.5,24,18,16$, and $6.8 \mathrm{~cm}$ depths, were selected for SEM-EDS analysis (LEO $435 \mathrm{VP}$ ). Four of them corresponded to sediment sections with high $\mathrm{Ca}$ concentrations and one $(16 \mathrm{~cm})$ to sediment located between Ca-rich and $\mathrm{K}$-rich sections. The aim was to determine the presence of material of volcanic origin and the possible sedimentary processes responsible for its transport to the lake.

The analytical instruments used are hosted in the RIAIDT (Infrastructure Network for the Support of Research and Technological Development) facility of the University of Santiago de Compostela.

\subsection{Core chronology}

The chronology of the core LIM03/1 was constructed using ${ }^{210} \mathrm{~Pb},{ }^{226} \mathrm{Ra}$, and ${ }^{137} \mathrm{Cs}$ measurements and radiocarbon dating of two moss samples. This chronology was overlapped with radiocarbon dating of moss samples of another long core collected in 2008 at the same lake location. The Bacon script for R (Blaauw and Christen, 2011) was used to construct the age model of the composite core. The details can be found in Toro et al. (2013).

\subsection{Statistical analysis}

Principal components analysis (PCA) was performed on the geochemical data to extract the main chemical signatures of the sediment elemental composition and investigate into the factors controlling them. Since compositional data are a case of closed data (Aitchison et al., 2002; Baxter et al., 2008), a centred log ratio (CLR) transformation was applied prior to the statistical analysis (Aitchison, 2003; Baxter and Freestone, 2006). A varimax rotation was chosen for the final PCA model. This type of rotation maximizes the loadings of the variables on the components. In the particular case of depth records, it results in the allocation to the same component of variables sharing a large proportion of their variance, that is, chemical elements showing very similar records, enabling an easier identification and interpretation of the underlying factors (Kylander et al., 2013).

Correlation analysis was used to establish the relation between the elemental composition and the mineralogy. All correlation coefficients mentioned in the text are highly significant $(p<0.01)$ unless otherwise stated. Both PCA and correlation analysis were performed using the statistical software SPSS 20.0.

\section{Results}

\subsection{Elemental composition}

The concentration records of the analyzed elements can be found in Fig. 2. To summarize the geochemical composition and investigate into the underlying factors, as already indicated in the Methods section, we have applied principal components analysis to the CLR transformed data. Seven components explained almost $96 \%$ of the total variance (Table 1). The first component (Cp1, $40.6 \%$ of the variance) shows large positive loadings of $\mathrm{Ca}, \mathrm{Sr}, \mathrm{Ti}$, and $\mathrm{Zr}$ and large negative loadings of $\mathrm{K}$ and $\mathrm{Rb}$ (Table 1). The record of $\mathrm{Cp} 1$ scores (Fig. 3) is characterized by a see-saw pattern, particularly in the upper $35 \mathrm{~cm}$, with four well-defined peaks of positive scores (i.e. high concentrations of $\mathrm{Ca}, \mathrm{Sr}, \mathrm{Ti}$, and $\mathrm{Zr}$ and low concentrations of $\mathrm{K}$ and $\mathrm{Rb}$ ) centred at 30.5 (L4), 24.0 (L3), 18.0 (L2), and $6.7 \mathrm{~cm}$ (L1) depths. The sediment section below $35 \mathrm{~cm}$ shows almost constant negative scores (i.e. high concentrations of $\mathrm{K}$ and $\mathrm{Rb}$ and low concentrations of $\mathrm{Ca}, \mathrm{Sr}, \mathrm{Ti}$, and $\mathrm{Zr}$ ).

The second component (Cp2, $12.7 \%$ of the variance; Table 1) is characterized by large positive loadings for $\mathrm{Fe}$ and $\mathrm{Mn}$. The record of $\mathrm{Cp} 2$ scores (Fig. 3) shows a trend of slightly increasing values from 60 to $27 \mathrm{~cm}$, and a steady decrease from this depth to the surface - with three distinctive peaks at $14-16 \mathrm{~cm}, 7.6$, and $3.2 \mathrm{~cm}$.

The third component (Cp3, $12.2 \%$ of variance; Table 1) shows large positive loadings for $\mathrm{Si}$ and $\mathrm{Al}$. The scores are around zero (i.e. close to average concentrations of $\mathrm{Si}$ and $\mathrm{Al}$ ) in the whole core (Fig. 3), with the exception of three negative excursions at 23.0, 20.0, and $2.7 \mathrm{~cm}$ depths.

The fourth to seventh components $(\mathrm{Cp} 4-\mathrm{Cp} 7)$ are represented by only one metallic element each: $\mathrm{Cu}, \mathrm{Zn}, \mathrm{Pb}$, and $\mathrm{Cr}$, and account for a $7.8-7.3 \%$ of the total variance (Table 1). The records of $\mathrm{Cp} 4$ to $\mathrm{Cp} 6$ scores have in common an overall lower variability, no systematic change below $20 \mathrm{~cm}$ and a relatively higher variability in the section above this depth (Figs. 2 and 3). $\mathrm{Cp} 4(\mathrm{Cu})$ and $\mathrm{Cp} 7(\mathrm{Cr})$, as well as $\mathrm{Cp} 3$ ( $\mathrm{Fe}$ and $\mathrm{Mn}$ ), show a peak in scores coinciding with the uppermost peak in Cp1 scores (L1, Figs. 2 and 3), but not in the other sections with high Cp1 scores (L2 to L4, Fig. 3). $\mathrm{Cp} 7(\mathrm{Cr})$ is the only chemical component showing a trend of increasing values to the surface of the core (Figs. 2 and 3). The larger variability in the upper $20 \mathrm{~cm}$ probably responds to the higher resolution of sectioning and number of samples analyzed.

\subsection{Mineralogical composition and SEM-EDS analysis}

In all samples analyzed by XRD, a broad band centred on $22^{\circ} 2 \Theta$ indicated the presence of non-crystalline inorganic material. This effect was more evident in the samples of the upper $9 \mathrm{~cm}$. The quantification provided in Fig. 4 only refers to the crystalline mineral phases identified. 
Table 1. Loadings of the chemical elements used in the principal components analysis. $\mathrm{Cp} 1$ to $\mathrm{Cp} 7$ - components; Com - communality (i.e. proportion of the variance of each element explained by the extracted components); Eigv - eigenvalue, Var - percentage of explained variance by each component.

\begin{tabular}{lrrrrrrrr}
\hline & $\mathrm{Cp} 1$ & $\mathrm{Cp} 2$ & $\mathrm{Cp} 3$ & $\mathrm{Cp} 4$ & $\mathrm{Cp} 5$ & $\mathrm{Cp} 6$ & $\mathrm{Cp} 7$ & Com \\
\hline $\mathrm{Ti}$ & $\mathbf{0 . 9 6}$ & 0.06 & 0.04 & 0.14 & 0.02 & -0.09 & -0.08 & 0.96 \\
$\mathrm{Ca}$ & $\mathbf{0 . 9 6}$ & 0.06 & 0.02 & 0.07 & -0.13 & -0.11 & 0.15 & 0.98 \\
$\mathrm{Sr}$ & $\mathbf{0 . 9 4}$ & 0.23 & 0.02 & 0.06 & -0.09 & -0.04 & 0.13 & 0.97 \\
$\mathrm{Zr}$ & $\mathbf{0 . 9 4}$ & 0.11 & 0.03 & 0.19 & 0.04 & 0.05 & 0.08 & 0.97 \\
$\mathrm{~K}$ & $\mathbf{- 0 . 8 9}$ & -0.11 & 0.08 & -0.03 & 0.29 & 0.13 & 0.04 & 0.95 \\
$\mathrm{Rb}$ & $\mathbf{- 0 . 9 4}$ & -0.06 & -0.05 & -0.04 & 0.23 & 0.16 & -0.01 & 0.92 \\
$\mathrm{Fe}$ & 0.07 & $\mathbf{0 . 9 1}$ & -0.24 & 0.11 & 0.12 & 0.09 & -0.13 & 0.94 \\
$\mathrm{Mn}$ & 0.38 & $\mathbf{0 . 8 4}$ & -0.00 & 0.08 & 0.01 & -0.15 & -0.23 & 0.93 \\
$\mathrm{Si}$ & 0.02 & -0.05 & $\mathbf{0 . 9 5}$ & 0.16 & -0.07 & 0.04 & -0.07 & 0.94 \\
$\mathrm{Al}$ & 0.04 & -0.21 & $\mathbf{0 . 8 4}$ & -0.33 & 0.15 & 0.13 & -0.00 & 0.90 \\
$\mathrm{Cu}$ & 0.27 & 0.15 & -0.05 & $\mathbf{0 . 9 3}$ & 0.08 & -0.04 & 0.12 & 0.97 \\
$\mathrm{Zn}$ & -0.32 & 0.12 & 0.04 & 0.08 & $\mathbf{0 . 9 2}$ & -0.09 & -0.01 & 0.97 \\
$\mathrm{~Pb}$ & -0.20 & -0.02 & 0.13 & -0.04 & -0.07 & $\mathbf{0 . 9 6}$ & -0.02 & 0.99 \\
$\mathrm{Cr}$ & 0.11 & -0.29 & -0.07 & 0.12 & -0.01 & -0.02 & $\mathbf{0 . 9 4}$ & 0.99 \\
$\mathrm{Eigv}$ & 5.69 & 1.78 & 1.71 & 1.10 & 1.10 & 1.0 & 1.0 & \\
$\mathrm{Var}$ & 40.6 & 12.7 & 12.2 & 7.8 & 7.5 & 7.5 & 7.3 & \\
\hline
\end{tabular}

Plagioclase $(66 \pm 11 \%), 2: 1$ phyllosilicates (probably chlorite-smectites, $22 \pm 10 \%)$, and quartz $(12 \pm 3 \%)$ are the main crystalline minerals. In samples at 11.7 and $44.5 \mathrm{~cm}$ depths, traces of a zeolite $(<1 \%)$ of the clinoptilolite group (effects and 8.9 and $3.9 \mathrm{~nm}$ ) were also found. In some samples there are effects $(0.26 \mathrm{~nm})$ that may correspond to antarcticite, but most of the other effects of this mineral overlap with those of plagioclase and it is difficult to resolve its presence.

Plagioclase content varies between a minimum of $45 \%$ at $50.5 \mathrm{~cm}$ and a maximum $83 \%$ at $16.8 \mathrm{~cm}$ and tends to be higher in Ca-rich samples (Fig. 4); $2: 1$ phyllosilicates range between $5 \%$ (at $18.8 \mathrm{~cm}$ ) and $40 \%$ (at $40.5 \mathrm{~cm}$ ) and tend to be higher in K-rich sections (Fig. 4); and quartz ranges between a minimum of $6 \%$ (at $18.8 \mathrm{~cm}$ ) and a maximum of $16 \%$ (at $44.5 \mathrm{~cm}$ ) and also tends to be more abundant in Krich sections. Plagioclase is highly correlated with $\mathrm{Cp} 1(r$ 0.77; Table 2) and, consequently, with $\mathrm{Ca}, \mathrm{Sr}, \mathrm{Ti}$, and $\mathrm{Zr}(r$ 0.73-0.77; Table 2); $2: 1$ phyllosilicates are positively correlated to $\mathrm{K}$ and $\mathrm{Rb}(0.48$ and 0.59 , Table 2$)$ but negatively correlated to $\mathrm{Ca}, \mathrm{Ti}, \mathrm{Sr}$, and $\mathrm{Zr}$ ( -0.58 to -0.66 ; Table 2$)$; quartz shows the same correlation pattern than the $2: 1$ phyllosilicates but the correlation coefficients are larger $(r 0.71$ and 0.80 with $\mathrm{K}$ and $\mathrm{Rb},-0.79$ to -0.88 for the other elements; Table 2).

The samples selected for SEM-EDS analysis corresponded to the four main peaks with higher $\mathrm{Ca}$ (and $\mathrm{Ti}, \mathrm{Zr}$, Sr) concentrations, plus one sample located at $16 \mathrm{~cm}-$ between the peak at $18 \mathrm{~cm}$ and the low at $12 \mathrm{~cm}$. All of them had large amounts of volcanic shards with angular, sharp edges (Fig. 5). The shards had the overall composition of a plagioclase ( $\mathrm{Si}, \mathrm{O}, \mathrm{Al}, \mathrm{Ca}$, and $\mathrm{Na}$ ), although differences were
Table 2. Correlation between mineralogy and elemental composition. Pg - palgioclase; 2: 1 Phy - 2: 1 phyllosilicates; Qtz - quartz; Cp1 - first PCA component.

\begin{tabular}{lrrr}
\hline & Plag & $2: 1$ Phy & Qtz \\
\hline $\mathrm{Cp} 1$ & 0.77 & -0.66 & -0.85 \\
$\mathrm{Ca}$ & 0.76 & -0.66 & -0.79 \\
$\mathrm{~K}$ & -0.59 & 0.48 & 0.71 \\
$\mathrm{Ti}$ & 0.71 & -0.58 & -0.88 \\
$\mathrm{Rb}$ & -0.71 & 0.59 & 0.80 \\
$\mathrm{Sr}$ & 0.75 & -0.65 & -0.79 \\
$\mathrm{Zr}$ & 0.73 & -0.60 & -0.85 \\
\hline
\end{tabular}

found in the Fe and Ti content (Fig. 5). Diatoms were also present, particularly in the sample at $16 \mathrm{~cm}$.

\section{Discussion}

\subsection{Elemental and mineralogical composition of the lake sediments}

There are few studies dealing with the elemental composition of rocks, soils, and lake sediments of the Byers Peninsula. Among them, it is worth mentioning that by Navas et al. (2008), which provides elemental data of soils derived from different geological materials of the area; the study by Otero et al. (2013) on the content of micronutrients (Fe, Mn, $\mathrm{Co}$, and $\mathrm{Cu}$ ) in soils of the Byers Peninsula; and the study by Björck and Zale (1996b) on the composition of tephras found in lake sediments of the Byers Peninsula. The paper by Toro et al. (2013), on a composite sediment core sampled 


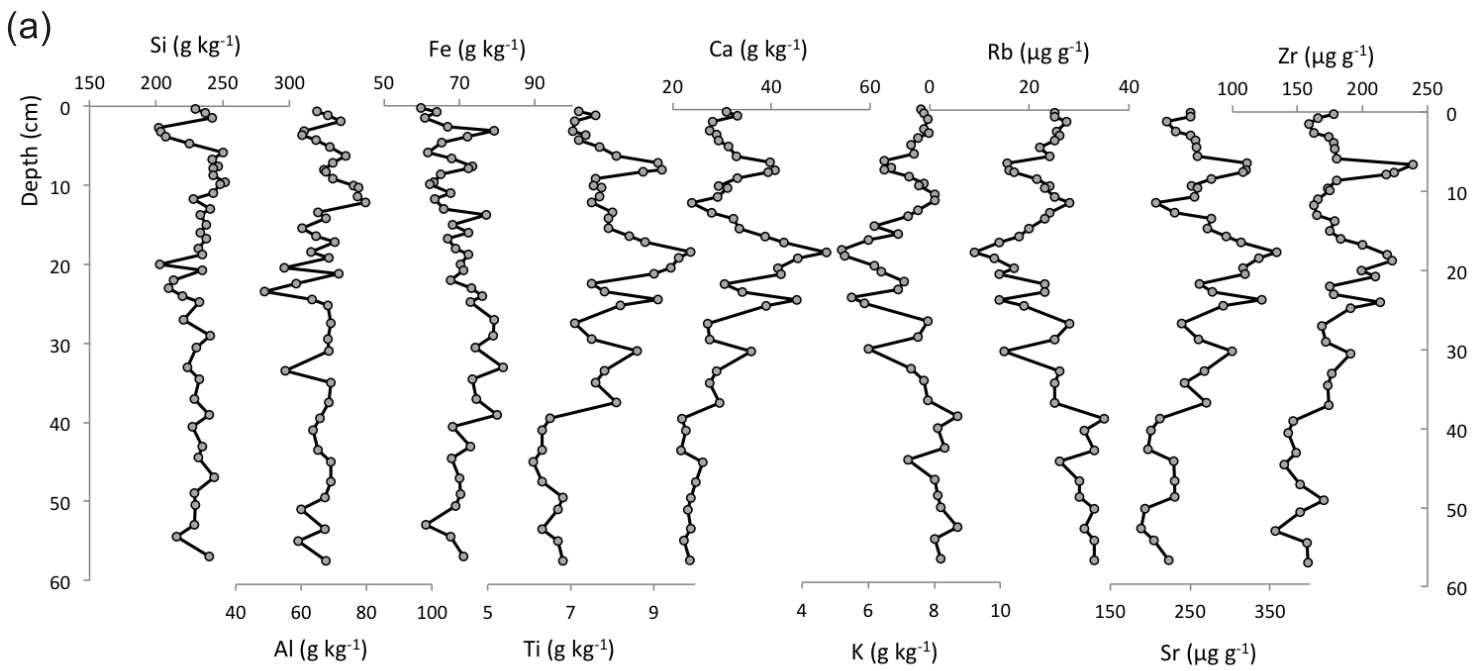

(b)
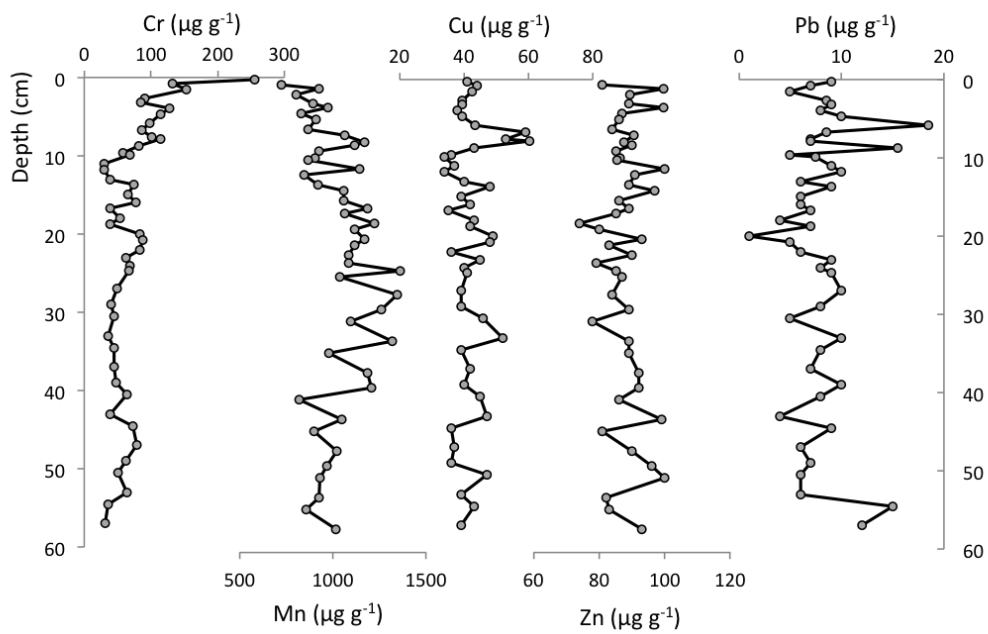

Figure 2. Depth records of concentrations of the elements analyzed in the LIM03/1 core of Limnopolar Lake. (a) Major, minor, and trace lithogenic elements; (b) metallic elements.

at Limnopolar Lake, is also of reference, but a quantitative comparison of the elemental composition cannot be made since they used a core scanner and the data is presented as counts per second. Also, here we do not present data for two of the elements included by Toro et al. (2013), $\mathrm{Cl}$ and $\mathrm{Co}$, but provide data for other four elements $(\mathrm{Rb}, \mathrm{Cr}, \mathrm{Zn}, \mathrm{Pb})$, plus LIM03/1 contains the upper $10 \mathrm{~cm}$ that are lacking in the composite core.

For $\mathrm{Al}, \mathrm{Fe}, \mathrm{Sr}, \mathrm{Cr}$, and $\mathrm{Cu}$, the concentrations in the sediments of Limnopolar Lake (Fig. 2) are much higher than those given for the soils of the area (both those developed on marine sediments and on volcanic materials; Navas et al., 2008; Otero et al., 2013), but similar to those of the tephras found in lake sediments (Björck and Zale, 1996b). For Ca, $\mathrm{K}, \mathrm{Mn}$, and $\mathrm{Zn}$, concentrations are within the range found for soils and tephras. Data on Si and Ti concentrations have been published only for tephra layers (Björck and Zale, 1996b), and are similar to those found by us.

Our results on the mineralogical composition of these sediments are comparable to those of studies done in sediments and soils of the area (Jeong et al., 2004; Navas et al., 2005), in particular regarding the high contents of plagioclase. The presence of zeolite was also noted by the cited investigations. The main mineralogical changes in Limnopolar Lake sediments are mostly related to the abundance of $2: 1$ phyllosilicates (mica, smectite, and interlayered minerals). The lower section of the core $(>35 \mathrm{~cm})$ is the one with the highest abundance of phyllosilicates, for which the composition is similar to that of sediments of the marine platform of the South Shetland Islands studied by Jeong et al. (2004). The clay fraction of these sediments was found to be enriched in smectite $(63 \%)$, in comparison to chlorite $(25 \%)$ and illite 


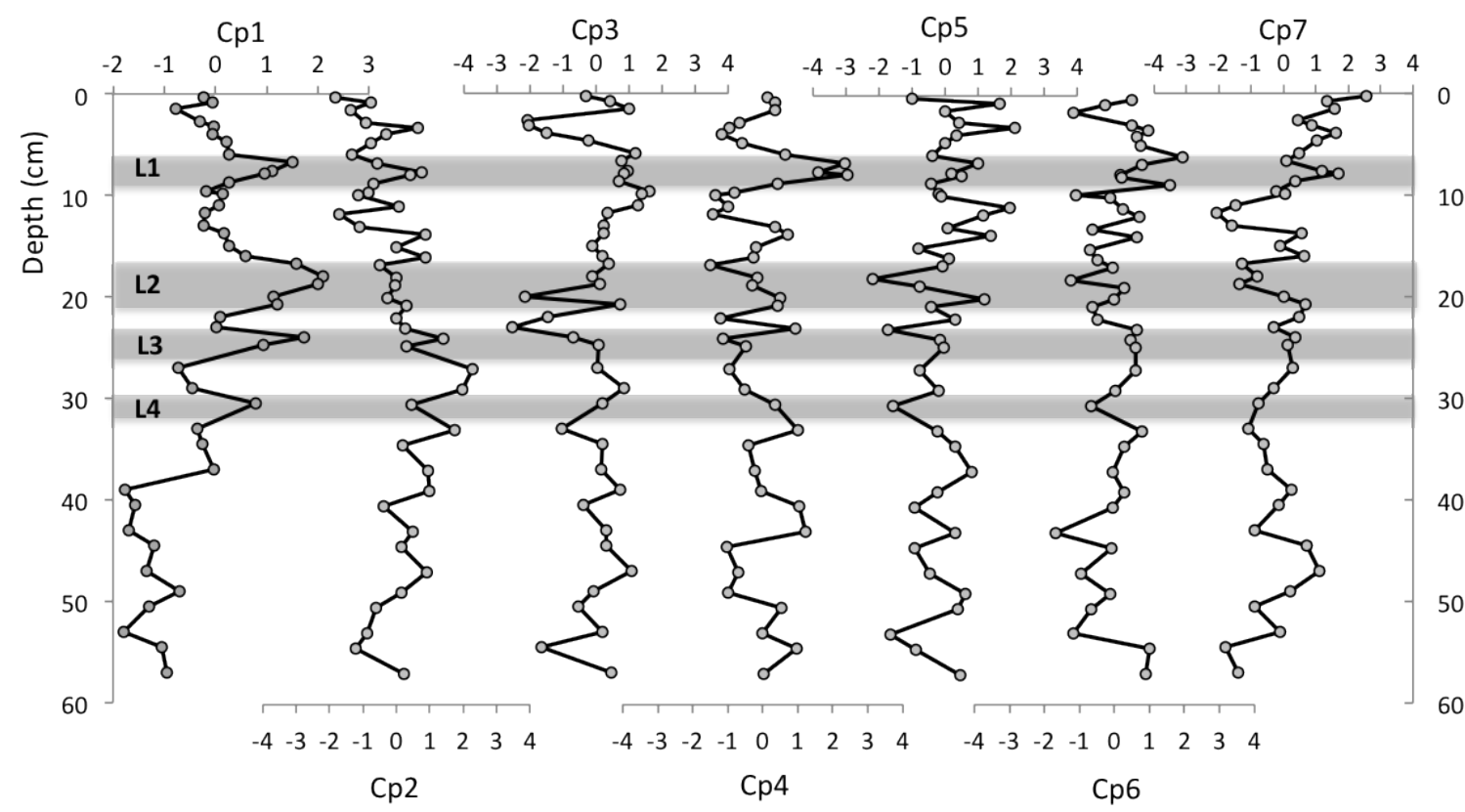

Figure 3. Depth records of scores of the principal components extracted by PCA on the elemental composition of the sediments of the core LIM03/1 of Limnopolar Lake. L1 to L4: layers enriched in Ca, Ti, Zr, and Sr, which are interpreted as tephras.

(12\%), also showing high concentrations of $\mathrm{K}$ and Fe (Jeong et al., 2004).

The LIM03/1 core represents the uppermost $57 \mathrm{~cm}$ of the composite sediment sequence studied by Toro et al. (2013) in Limnopolar Lake sediments. Although the long sequence does not include the uppermost $10 \mathrm{~cm}$, the short core analyzed by us should correspond to the mineralogical Zone 3 of Unit 2, defined by these authors. The zone starts at $144 \mathrm{~cm}$ and extends to the top of the core, being characterized by a roughly constant mineralogy dominated by mineral phases typical of volcaniclastic material (albite, illite and quartz), its chemical alteration products (montmorillonite, saponite, talc and chlorite), and marine salt input (gypsum and antarcticite). The results for LIM03/1 are comparable - with dominance of plagioclase and 2:1 phyllosilicates. We were not able to corroborate the presence of minerals related to sea spray input described by Toro et al. (2013) in the composite core. Antarcticite is a highly hygroscopic mineral that may have transformed during the drying of the samples, while gypsum is only present in a few sections of Zone 3 and it is not surprising that it is absent in LIM03/1. We did not identify separately the chemical alteration products, including them in the group of $2: 1$ phyllosilicates due to the lower resolution of the XRD equipment used for this study.

\subsection{Controls on sediment inorganic geochemistry}

The sediments of Limnopolar Lake have a contrasted chemical and mineralogical composition, as synthesized by the first principal component (Fig. 3). Large shifts between layers enriched in $\mathrm{K}$ and $\mathrm{Rb}$, with higher contents of quartz and $2: 1$ phyllosilicates, and sediments enriched in $\mathrm{Ca}, \mathrm{Sr}, \mathrm{Ti}$, and $\mathrm{Zr}$ with larger abundance of plagioclase and occasional presence of zeolites, occur in the $57 \mathrm{~cm}$ of the analyzed core. As the SEM-EDS results demonstrate, the Ca-rich sections contain abundant volcanic shards indicating they may correspond to tephra layers with a calc-alkaline composition. On the other hand, K-rich sections may correspond to sediments with a higher content of material eroded from the lake catchment, since it is dominated by marine sediments of a Jurassic-Lower Cretaceous age. Thus, during periods of low volcanic activity, the geochemical signal of the sediment was controlled by the input of terrigenous material provided by the catchment, while in periods of volcanic activity it was controlled by the supply of volcanic material. This is also supported by the results obtained for quartz and $2: 1$ phyllosilicates contents, since they are negatively correlated to elements related to volcanic material and positively correlated to those related to the marine sediments. Quartz is typically depleted in basic and ultrabasic geological materials, while it is enriched in acidic ones and in many sedimentary rocks due to its resistance to weathering.

When compared to the results obtained by Toro et al. (2013), LIM03/1 shows a more contrasted mineralogical and compositional pattern. For example, while in the short core $\mathrm{Ca}$ is inversely correlated to the elements characterising the terrigenous material $(r-0.87$ with $\mathrm{K}$ and -0.95 with $\mathrm{Rb}$ ), in the composite long core $\mathrm{Ca}$ and $\mathrm{K}$ are positively correlated $(r$ 0.67). This may be due to LIM03/1 representing a short time period with relatively more frequent volcanic 


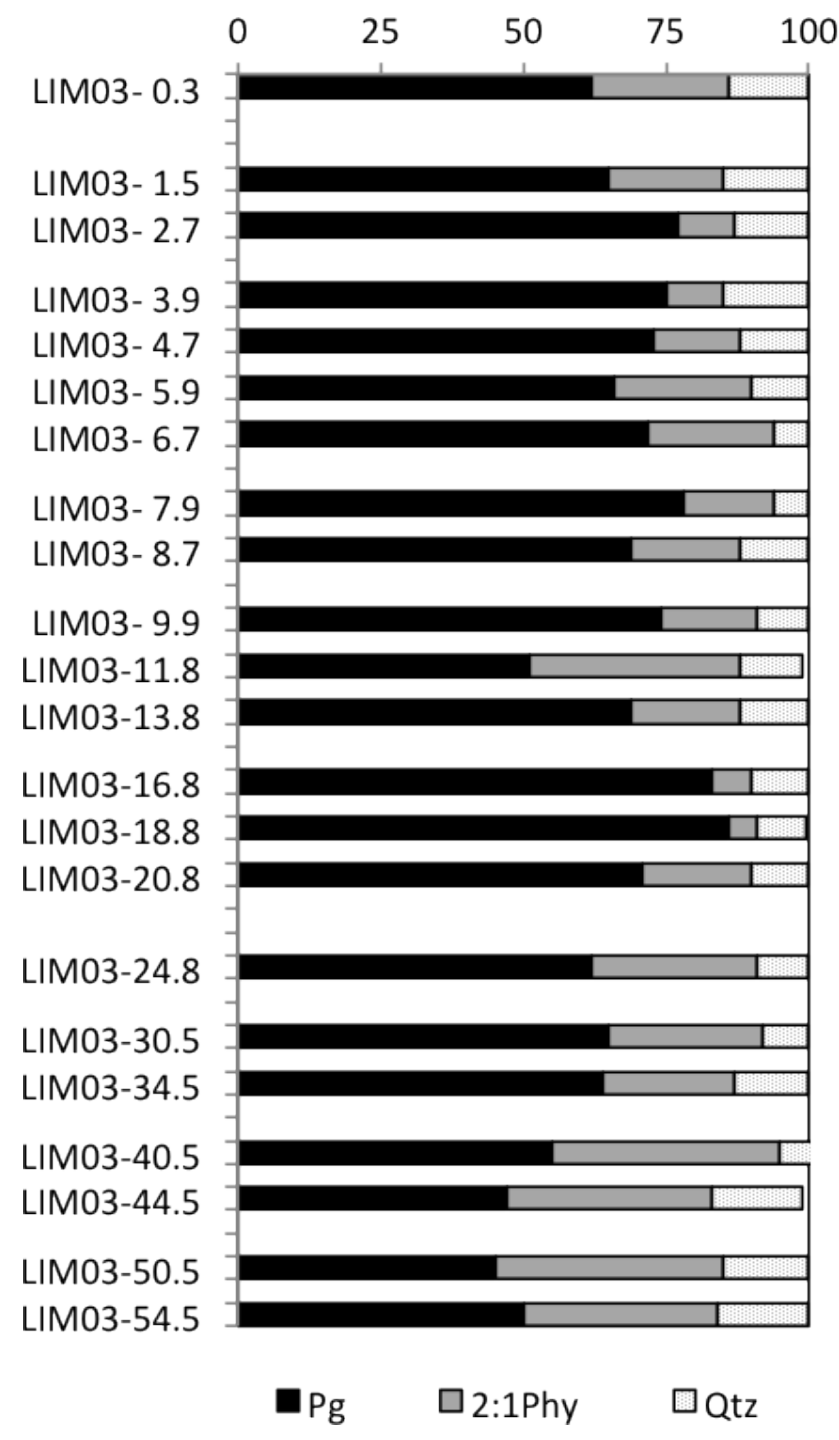

Figure 4. Mineralogical composition of selected samples of the sediments of LIM03/1 core of Limnopolar Lake. Pg - palgioclase; $2: 1$ Phy - 2: 1 phyllosilicates; Qtz - quartz.

events, which may result in a maximization of the differences between the two identified geochemical signals.

As for the volcanic material, it may have been directly deposited into the lake (i.e. tephra layers) but it may also have been supplied by runoff from the catchment after the volcanic eruption (reworked volcanic material). The morphology of the volcanic shards observed by SEM (Fig. 5) and the abrupt limits of three of the proposed tephra layers (L1, L3, L4), suggest that most of this volcanic material corresponds to fallout ashes deposited either directly into the lake, if the eruption occurred during ice-free lake periods, or on the ice cover, if the the volcanic event took place during the winter and the material was later incorporated to the lake sediments owing to the summer ice melt. A supply from the catchment shortly after the deposition of the ashes cannot be ruled out.
Support for this interpretation is found in the fact that $\mathrm{Cp} 1$ scores in the upper $35 \mathrm{~cm}$, the section reflecting a higher volcanic activity, do not return to values similar to those of the section below, and that the peak at $18 \mathrm{~cm}$ (L2, Fig. 3) shows a gradual decrease in scores and not the sharp termination found for the other peaks (L1, L3, L4; Fig. 3). So, as expected, both processes may have operated through time.

Previous research developed on lake sediments and ice caps of the Byers Peninsula already demonstrated the presence of tephra layers (Björck et al., 1991; Björck and Zale, 1996b; Hodgson et al., 1998; Pallás et al., 2001), mostly attributed to the volcanic activity on Deception Island, located $30 \mathrm{~km} \mathrm{SE}$ of the peninsula. Toro et al. (2013) also found that the geochemical composition of most glass shards of the composite long core was similar to those of this volcano. The relation to the tephrochronology proposed by the mentioned investigations, and extended by Toro et al. (2013), is discussed in the next section.

The second chemical signature (Cp2) of the LIM03/1 core is related to the covariation in $\mathrm{Fe}$ and $\mathrm{Mn}$ contents, both elements which have in common their redox behaviour. The record of scores (Fig. 3) shows a moderate, and irregular, enrichment until $27 \mathrm{~cm}$ and a slight decrease below this depth. Post-depositional redistribution of these two elements has been shown to occur in reducing environments (Chesworth et al., 2006; Naeher et al., 2013). On the other hand, the lake is shallow and strong reducing conditions seem to be unlikely unless during periods of prolonged ice cover (inverse lake stratification) that may have resulted in a depletion of oxygen. Punctual measurements performed under the ice cover the 15 December 2012 revealed anoxic conditions in the lower $1.5 \mathrm{~m}$ of the lake water column, and methane release occurred during the extraction of long-cores in 2008. Anoxic conditions and pyrite formation was found to occur in lake-bottom sediments of deep areas of Lake Hoare, located in the Dry Valleys region of Antarctica (Bishop et al., 2001). As for the hosting Fe-Mn phases, the SEM-EDS analyses have shown that the volcanic shards do contain variable amounts of $\mathrm{Fe}$ and $\mathrm{Mn}$, although their concentrations show no correlation with the abundance of minerals of volcanic origin.

The third chemical signature (Cp3; Fig. 3 ) is the association between $\mathrm{Si}$ and $\mathrm{Al}$, which probably represents variations in an aluminosilicate phase. This may well be a mineral present in trace amounts since no correlation was found between Cp3 scores and the abundance of any of the identified minerals, and changes in the record are minor except for the mentioned three negative excursions.

Of the metal signals, $\mathrm{Zn}$ and $\mathrm{Pb}$ (Cp5 and Cp6; Fig. 3) present irregular depth distributions with no apparent trend. Copper (Cp4), on the other hand, is high in layer L1 of volcanic material, where $\mathrm{Fe}, \mathrm{Mn}$, and $\mathrm{Cr}$ (Cp2, Cp7; Fig. 3) also show a more or less well-defined peak. None of the other layers of volcanic material have elevated concentrations of these metals. Matthies et al. (1990) found changes 

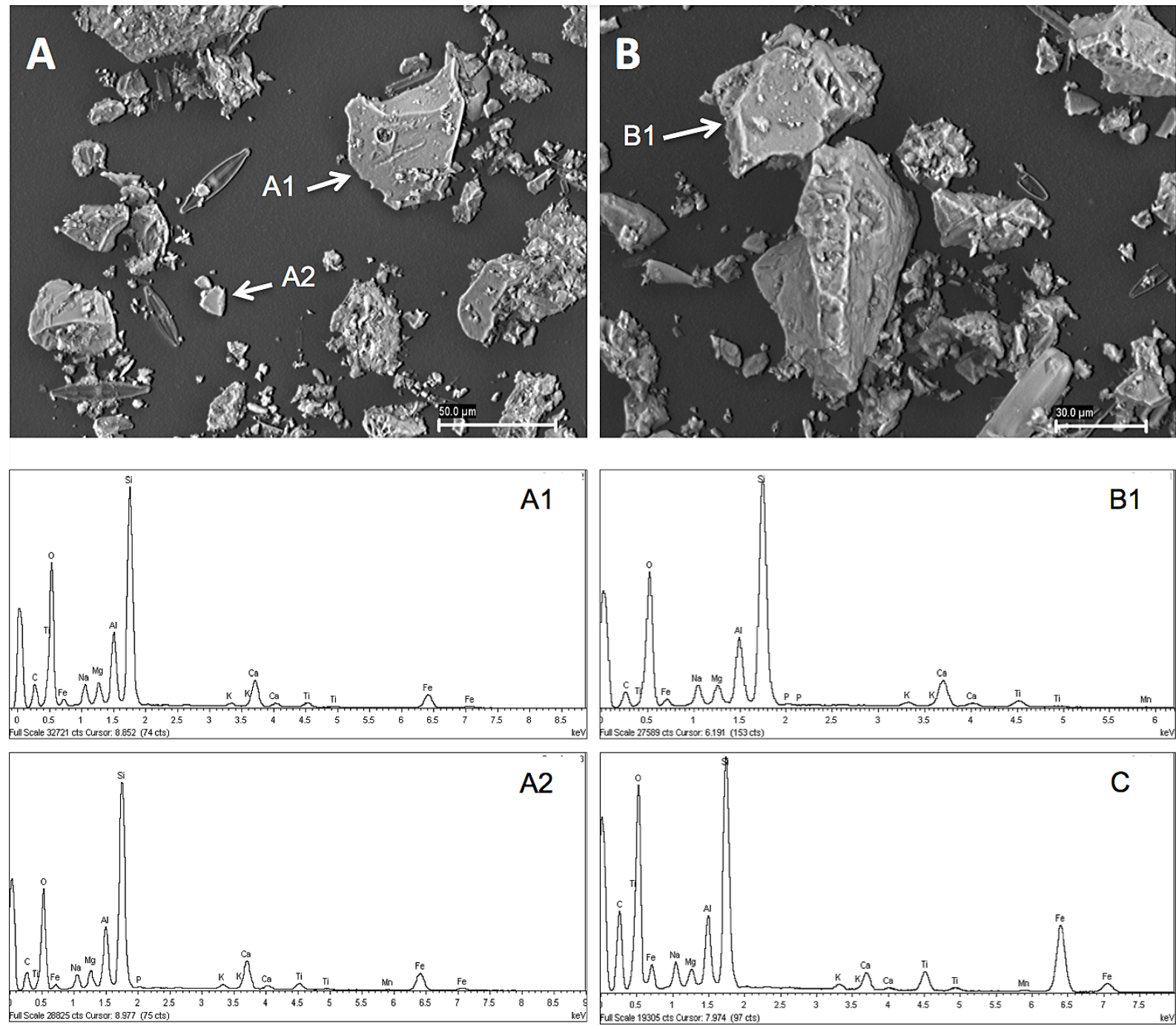

Figure 5. Selected SEM microphotographs showing the presence of volcanic shards in Ca-rich layers of sediments of the core LIM03/1 of Limnopolar Lake, and EDS analyses of their composition. A1, A2 and B1 correspond to the shards coded in the microphotographs (A) (tephra at $18 \mathrm{~cm}$ ) and $(\mathbf{B})$ (tephra at $6.8 \mathrm{~cm})$; (C) (tephra at $6.8 \mathrm{~cm}$ ) is an example of a shard richer in $\mathrm{Fe}$ and $\mathrm{Ti}$ (not shown in the microphotographs).

in the chemical composition of tephras from Deception Island volcano, while Björck and Zale (1996b) found that the last tephra layer recorded in lake sediments of Byers Peninsula has differences in chemical composition in comparison with previous tephras (in particular, $\mathrm{Cu}$ concentration was higher). In the composite long core of Limnopolar Lake studied by Toro et al. (2013), Cu was found to be associated with talc, thus some of the minor changes observed in $\mathrm{Cu}$ concentration in LIM03/1 may have depended on the abundance of this mineral. Nevertheless, contribution from other volcanic sources cannot be ruled out. In Midge Lake, Hogdson et al (1998) found a single acidic tephra at $2-3 \mathrm{~cm}$; while Fretzdorff and Smellie (2002), in a study of tephra layers in sediments of the central Brandsfield basin, found that the composition of the uppermost layer did not match to any known Antarctic-Scotia Sea-Southern South America region source and, given its shallow stratigraphical position, concluded that the source volcano should have been active in historical times (a few hundred years at most).

Chromium (Cp7, Fig. 3) is the only metal that shows a steady increase in concentrations in the upper $10 \mathrm{~cm}$, the average concentration in this section being twofold that of the sediments below $\left(115 \pm 41 \mu \mathrm{g} \mathrm{g}^{-1}\right.$ vs. $\left.55 \pm 18 \mu \mathrm{g} \mathrm{g}^{-1}\right)$.

Taken together, the data on metals do not point to significant effects from recent anthropogenic pollution in Byers Peninsula. This is in agreement with studies on trace metal contamination in Antarctic ecosystems (Bargagli, 2000, 2008; Sánchez-Hernández, 2000), indicating that $\mathrm{Pb}$ is probably the only metal whose biogeochemical cycle has been significantly affected by anthropogenic emissions (Sun and Xie, 2001; Yin et al., 2006), and that in coastal ecosystems - like the Byers Peninsula - the input of metals from 
anthropogenic sources and from long-range transport is negligible. Rose et al. (2012) reached the same conclusion in a study of the presence of fly ash particles in lake sediments of the Falkland Islands and Antarctica. Although detectable, the content of fly ash particles in sediments of Antarctic lakes was very low, while in the Falkland Islands the record extended back to the 19th century and showed a much higher impact of contamination.

In Antarctica, metal pollution has been found to be restricted to small areas within the surroundings of research stations, affecting both soils and continental and marine waters (Claridge et al., 1995; Crockett, 1998; Sheppard et al., 2000; Crockett and White, 2003; Webster et al., 2003; Santos et al., 2006; Chaparro et al., 2007). Thus, the remote position of Livingston Island and the modest research infrastructures it hosts may explain the lack of pollution evidence in the sediments of Limnopolar Lake.

\subsection{Chronology of the main geochemical changes}

The LIM03/1 short core represents the sediment accumulation in Limnopolar Lake during the last ca. 1600 years. The main temporal changes in sediment geochemistry are represented in Fig. 6. The record of $\mathrm{Cp} 1$ scores reflects the input of volcanic material (fallout ashes and reworked material) to the lake, most probably related to the activity of the Deception Island volcano. As already mentioned, previous investigations (Björck et al., 1991; Björck and Zale, 1996a; Hodgson et al., 1998; Pallés et al., 2001; Fretzdorff and Smellie, 2002) studied the chronology of tephras in the Antarctic Peninsula, which was recently extended and discussed by Toro et al. (2013). With the limitations stated above, the four peaks (L1 to L4; Fig. 3) with high positive Cp1 scores can be interpreted as events of tephra deposition to the lake, with ages of ADca. 1300 for L4, ADca. 1450-1470 for L3, AD ca. 1570-1650 for L2, and AD ca. 1840-1860 for L1. The depths of these layers in LIM03/1 are somewhat shallower than those of the upper tephras of the composite Limnopolar core, probably due to differences in compaction during coring or changes in the microtopography of the sediment surface. But their timing matches quite well with those given by Toro et al. (2013): ages of ca. $650-565$ cal yr BP (AD ca. 1300-1385), ca. 505-410 cal yr BP (AD ca. 14451540 ), ca. 365 cal yr BP (ADca. 1585; a peak in magnetic susceptibility), and at ca. $135 \mathrm{cal}$ yr BP (AD ca. 1815). These layers were correlated to tephras AP3 to AP1 of the tephrochronology developed by Björck et al. (1991).

Most of the metals showed no consistent depth trend, so their chronologies are not considered here. As already mentioned for $\mathrm{Cu}$, the largest peak in concentrations matches the age of layer L1 (Fig. 6), while Cr shows the same peak and steadily increasing values in the last 200 years. This latter trend has been repeatedly found for trace metals (as $\mathrm{Pb}$ and $\mathrm{Hg}$ ) in several studies on diverse types of geoarchives in the Northern Hemisphere and related to anthropogenic at-

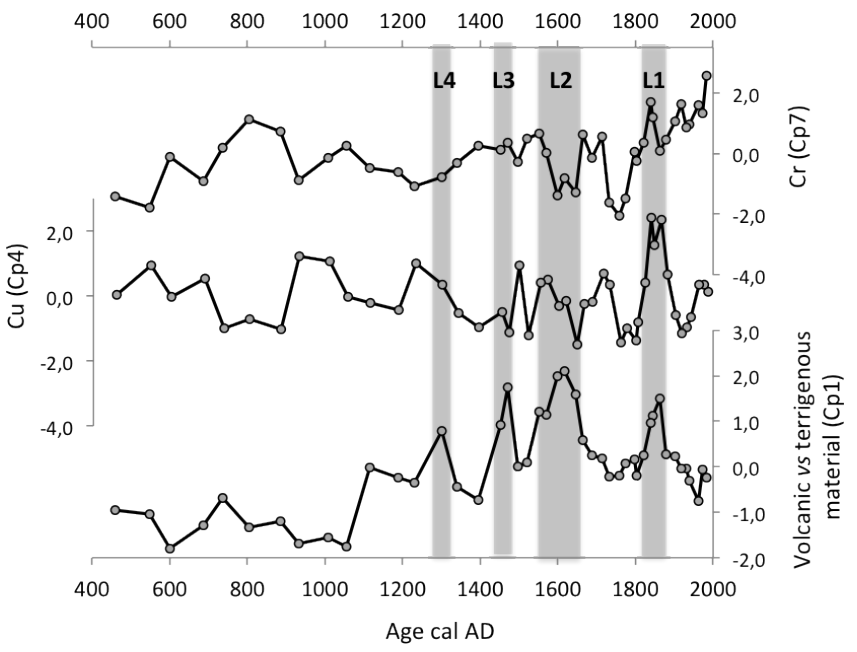

Figure 6. Chronology of the main changes in the chemical composition of the sediments of Limnopolar Lake during the last 1600 years. $\mathrm{L} 1$ to $\mathrm{L} 4$ : layers enriched in $\mathrm{Ca}, \mathrm{Ti}, \mathrm{Zr}$, and $\mathrm{Sr}$, which are interpreted as tephras.

mospheric pollution (Farmer et al., 1997, 2002; Renberg et al., 2002; Shotyk et al., 2003; Bindler et al., 2004; Martínez Cortizas et al., 2012). But recent research on deposition of dust and trace elements, including $\mathrm{Cr}$, in ice cores (Laluraj et al., 2014; Korotkikh et al., 2014) has shown that climatic variability (i.e. reduced moisture content and increased wind intensity) during the last decades may have resulted in enhanced fluxes to Antarctica.

It is also interesting to note that $\mathrm{Cr}, \mathrm{Cu}, \mathrm{Fe}$, and $\mathrm{Mn}$ concentrations, as well as the proportion of volcanic material, showed a minimum in sediment sections dated to the 18th century. The systematic low values in these components may be a consequence of other processes than those already described. Since the age of this excursion fits that of one of the coldest events of the Little Ice Age, the Maunder Minimum in solar insolation (Bard et al., 2000; Muscheler et al., 2007), climate change may have been also directly or indirectly involved in the cycling of elements in Antarctica as already proposed by other researchers (Bargagli, 2000).

\section{Conclusions}

The results obtained for the sediment core LIM03/1 indicate that volcanic activity has played a major role in the chemical and mineralogical composition of the sediments of Limnopolar Lake (Livingston Island, Antarctica) during the last ca. 1600 years. Both, direct deposition of tephras and redistribution of volcaniclastic material by runoff from the catchment, seem to have been particularly intense since at least AD ca. 1200. The most probable origin of the volcanic material is the Decpetion Island volcano, as found in previous investigations. Only in periods of low volcanic activity 
(from AD ca. 400 to AD ca. 1100), the composition of the sediments was controlled by the Jurassic-Lower Cretaceous marine sediments which dominate in the lake catchment.

The four layers (L1 to L4) rich in volcanic material contain abundant shards, as found by SEM-EDS analysis, with a chemical composition of a Ca-rich plagioclase and with ages that are quite similar to tephra layers previously identified in this and other lakes of Byers Peninsula.

The volcanic activity may have also been responsible for part of the changes observed for some of the trace metals analyzed ( $\mathrm{Fe}, \mathrm{Mn}, \mathrm{Cu}$, and $\mathrm{Cr}$ ), since they show peaks in concentrations coinciding with the tephra corresponding to layer L1. Apart from this, no evidence of enrichment has been found for the industrial period (last 300-200 years). As already suggested, the remote location of Livingston Island and the modest research infrastructures (non-permanent research camp and only two bases) may explain the lack of pollution evidence in the sediments of Limnopolar Lake. The only exception to this pattern is $\mathrm{Cr}$, for which a steady increase in concentrations has been found in the upper $10 \mathrm{~cm}$ of the core (i.e. the last 200 years) as it would be expected for a chronology of anthropogenic pollution since the onset of the industrial revolution. Nevertheless, as it has been recently proposed, increased $\mathrm{Cr}$ contents may have resulted from changes in climatic conditions around Antarctica.

Although speculative at this stage, some features of the elemental records, as the coincidence in minima of concentrations of some elements with recent, well-known, abrupt climate changes, may suggest a role of climate in the cycles of chemical elements in Antarctica. Again, more research is necessary to identify the actual mechanisms involved and support this interpretation.

Acknowledgements. This work was partially supported by projects CGL2010-20672 and REN2000-0345-ANT (Spanish Ministerio de Ciencia e Innovación), POL2006-06635/CGL (Spanish Ministerio de Educación y Cultura), and 10PXIB200182PR (Dirección Xeral de I+D, Xunta de Galicia). A. Quesada, A. Justel and C. Rochera, members of the Limnopolar Project team, are thanked for their help with coring in 2003.

Edited by: M. Oliva

\section{References}

Abollino, O., Aceto, M., Buoso, M., Gasparon, M., Green, W. J., Malandrino, M., and Mentasti, E.: Distribution of major, minor and trace elements in lake environments of Antarctica, Antarct. Sci., 16, 277-291, 2004.

Aceto, M., Sarzanini, C., Abollino, O., Sacchero, G., and Mentasti, E.: Distribution of minor and trace metals in Carezza Lake (Antarctica) ecosystems, Int. J. Environ. An. Ch., 55, 165-177, 1994.
Aitchison, J.: The statistical Analysis of Compositional Data, Backburn Press, Caldwell, New Jersey, 2003.

Aitchison, J., Barceló-Vidal, C., and Pawlowsky-Glahn, V.: Some comments on compositional data analysis in archaeometry, in particular the fallacies in Tangri and Wright's dismissal of logratio analysis, Archaeometry, 44, 295-304, 2002.

Bañón, M., Justel, A., Velazquez, D., and Quesada, A.: Regional weather survey on Byers Peninsula, Livingston Island, South Shetland Islands, Antarctica, Antarct. Sci., 25, 146-156, 2013.

Benayas, J., Pertierra, L., Tejedo, P., Lara, F., Bermudez, O., Hughes, K. A., and Quesada, A.: A review of scientific research trends within ASPA No. 126 Byers Peninsula, South Shetland Islands, Antarctica, Antarct. Sci., 25, 128-145, 2013.

Bard, E., Raisbeck, G. M., Yiou, F., and Jouzel, J.: Solar irradiance during the last 1200 years based on cosmogenic nuclides, Tellus B, 52, 985-992, 2000.

Bargagli, R.: Trace metals in Antarctica related to climate change and increasing human impact, Rev. Environ. Contam. Toxicol., 166, 129-137, 2000.

Bargagli, R.: Environmental contamination in Antarctic ecosystems, Sci. Total Environ., 400, 212-226, 2008.

Bargagli, R., Monaci, F., and Bucci, C.: Environmental biogeochemistry of mercury in Antarctic ecosystems, Soil Biol. Biochem., 39, 352-360, 2007.

Baxter, M. J. and Freestone, I. C.: Log-ratio compositional data analysis in archaeometry, Archaeometry, 48, 511-531, 2006.

Baxter, M. J., Beardah, C. C., Papageorgiou, I., Cau, M. A., Day, P. M., and Kilikoglou, V.: On statistical approaches to the study of ceramic artefacts using geochemical and petrografical data, Archaeometry, 50, 142-157, 2008.

Bindler, R., Klarqvist, M., Klaminder, J., and Foster, J.; Does within-bog variability of mercury and lead constrain reconstructions of absolute deposition rates from single peat records? The example of Store Moss, Sweden, Global Biogeochem. Cy., 18 , GB3020, doi:10.1029/2004GB002270, 2004.

Bishop, J. L., Koeberl, C., Kralik, C., Fröschl, H., Englert, P. A., Andersen, D. W., Pieters, C. M., and Wharton, R. A.: Reflectance spectroscopy and geochemical analyses of Lake Hoare sediments, Antarctica: implications for remote sensing of the Earth and Mars, Geochim. Cosmochim. Ac., 60, 765-785, 1996.

Bishop, J. L., Lougear, A., Newton, J., Doran, P. T., Froeschl, H., Trautwein, A. X., Körner, W., and Koeberl, Ch.: Mineralogical and geochemical analyses of Antarctic lake sediments: a study of reflectance and Mössbauer spectroscopy and C, N and S isotopes with applications to remote sensing on Mars, Geochim. Cosmochim. Ac., 65, 2875-2897, 2001.

Björck, S. and Zale, R.: Late Holocene tephrochronology and palaeoclimate, based on lake sediments studies, in: Geomorphological map of Byers Peninsula, Linvingston Island, edited by: López-Martínez, J., Thomson, M. R. A., and Thomson J. W., BAS GEOMAP Series, Sheet 5-A, 43-48, British Antarctic Survey, Cambridge, 1996a.

Björck, S. and Zale, R.: Appendix 1. Lithological description and geochemical data for lake sediments, in: Geomorphological map of Byers Peninsula, Linvingston Island, edited by: LópezMartínez, J., Thomson, M. R. A., and Thomson, J. W., BAS GEOMAP Series, Sheet 5-A, 59-62, British Antarctic Survey, Cambridge, $1996 \mathrm{~b}$. 
Björck, S., Hakansson, H., Zale, R., Kalén, R., and Johnsson, B. L.: A late Holocene lake sediment sequence from Livingston Island, South Shetland Islands, with palaeoclimatic implications, Antarct. Sci., 3, 61-72, 1991.

Blaauw, M. and Christen, J. A.: Flexible paleoclimate age-depth models using an autoregressive gamma process, Bayesian Analysis, 6, 457-474, 2011.

Chaparro, M. A. E., Nuñez, H., Lirio, J. M., Gogorza, C. S. G., and Sinito, A. M.: Magnetic screening and heavy metal pollution studies in soils from Mrambito Station, Atarctica, Antarct. Sci., 19, 379-393, 2007.

Cheburkin, A. K. and Shotyk, W.: An energy-dispersive miniprobe multi-element analyzer (EMMA) for direct analysis of $\mathrm{Pb}$ and other trace elements in peats, Fresen. J. Anal. Chem., 354, 688691, 1996.

Cheburkin, A. and Shotyk, W.: High sensitive XRF analyzer (OLIVIA) using a multi-crystal pyrographite assembly to reduce the continuous background, X-ray Spectrom, 28, 145-148, 1999.

Chesworth, W., Martínez Cortizas, A., García-Rodeja, E.: The redox-pH approach to the geochemistry of the Earth's land surface, with application to peatlands, in: Peatlands: Evolution and Records of Environmental and Climate Change, Martini, I. P., Martínez Cortizas, A., and Chesworth, W., Developments in Earth Surface Processes, 9, 175-195, 2006.

Claridge, G. G. C., Campbell, I. B., Powell, H. K. J., Amin, Z. H., and Balks, M. R.: Heavy metal contamination in some soils of the McMurdo Sound region, Antarctica, Antarct. Sci., 7, 9-14, 1995.

Convey, P., Bindschadler, R., Di Prisco, G., Fahrbach, E., Gutt, J., Hodgson, D. A., Mayeswki, P. A., Summerhayes, C. P., Turner, J., and ACCE Consortium: Antarctic climate and the environment, Antarct. Sci., 21, 541-563, 2009.

Crockett, A. B. and White, G. J.: Mapping sediment contamination and toxicity in Winter Quarters Bay, McMurdo station, Antarctica, Environ. Monit. Assess., 85, 257-275, 2003.

Crockett, A. B.: Background levels of metals in soils, McMurdo Station, Antarctica, Environ. Monit. Assess., 50, 289-296, 1998.

De Pablo, M. A., Blanco, J. J., Molina, A., Ramos, M., Quesada, A., and Vieira, G.: Interannual 19 active layer variability at the Limnopolar Lake CALM site on Byers Peninsula, Livingston 20 Island, Antarctica, Antarct. Sci., 25, 167-180, 2013.

Doran, P. T., Wharton, R. A., Lyons, W. B., Des Marais, D. J., Andersen, D. T.: Sedimentology and geochemistry of a perennially ice-covered epishelf lake in Bunger Hills Oasis, East Antarctica, Antarct. Sci., 12, 131-140, 2000.

Farmer, J. G., MacKenzie, A. B., Sudgen, C. L., Esdgar, P. J., and Eades, L. J.: A comparison of the historical lead pollutio records in peat and freshwater lake sediments from central Scotland, Water Air Soil Pollut., 100, 253-270, 1997.

Farmer, J. G., Eades, L. J., Atkins, H., and Chamberlain, D. F.: Historical trends in the lead isotopic composition of archival Sphagnum mosses from Scotland (1838-2000), Environ. Sci. Technol., 36, 152-157, 2002.

Fassnacht, S. R., López-Moreno, J. I., Toro, M., and Hultstrand, D. M.: Mapping Snow Cover and Snow Depth across the Lake Limnopolar Watershed on Byers Peninsula (Livingston Island) in Maritime Antarctica, Antarct. Sci., 25, 157-166, 2013.

Fretzdorff, S. and Smellie, J. L.: Electron microprobe characterization of ash layers in sediments from central Brandsfield basin (Antarctica Peninsula): evidence for at least two volcanic sources, Antarct. Sci., 14, 412-421, 2002.

Fuoco, R., Colombini, M. P., Ceccarini, A., and Abete, C.: Polychorobiphenyls in Antarctica, Microchem. J., 54, 384-390, 1996.

Hodgson, D. A., Dyson, C. L., Jones, V. J., and Smellie, J. L.: Thephra analysis of sediments from Midge Lake (South Shetland Islands) and Sombre Lake (South Orkney Islands), Antarctica, Antarct. Sci., 10, 13-20, 1998.

Jeong, G. Y., Yoon, H. I., and Lee, S. Y.: Chemistry and microstructures of clay particles in smectite-rich shelf sediments, South Shetland Islands, Antarctica, Mar. Geol., 209, 19-30, 2004.

Korotkikh, E., Mayewski, P. A., Dixon, D., Kurbatov, A. V., and Handley, M. J.: Recent increase in Ba concentrations as recorded in a South Pole ice core, Atnmos. Environ., 89, 683-687, 2014.

Kylander, M., Bindler, R., Martínez Cortizas, A., Gallagher, K., Mörth, C.-M., and Rauch, S.: A novel geochemical approach to paleorecords of dust deposition and effective humidity: 8500 years of peat accumulation at Store Mosse (the "Great Bog"), Sweden, Quaternary Sci. Rev., 69, 69-82, 2013.

Laluraj, C. M., Thamban, M., and Satheesan, K.: Dust and associated geochemical fluxes in a firn core from coastal East Antarctica and its linkages with Southern Hemisphere cliamte variability over the last 50 years, Atmos. Environ., 90, 23-32, 2014.

López-Martínez, J., Serrano, E., Martínez de Pisón, E.: Geomorphological features of the drainage system, in: Geomorphological map of Byers Peninsula, Livingston Island, edited by: LópezMartínez, J. and Thomson, M. R. A.: BAS GEOMAP Series, Sheet 5-A, Cambridge, British Antarctic Survey, 15-19, 1996.

Malandrino, M., Abollino, O., Buoso, S., Casalio, C. E., Gasparon, M., Giacomino, A., La Gioia, C., and Mentasti, E.: Geochemical characterisation of Antarctic soils and lacustrine sediments from Terra Nova Bay, Microchem. J., 92, 21-31, 2009.

Martínez Cortizas, A., Peiteado Varela, E., Bindler, R., Biester, H., and Cheburkin, A.: Reconstructing historical $\mathrm{Pb}$ and $\mathrm{Hg}$ pollution in NW Spain using multiple cores from Chao de Lamoso bog (Xistral Mountains), Geochim. Cosmochim. Ac., 82, 68-78, 2012.

Matthies, D., Mäusbacher, R., and Storzer, D.: Deception Island tephra: a stratigraphical marker for limnic and marine sediments in Bransfield Strait area, Antarctica, Zbl. Geol. Pal., 1, 153-165, 1990.

Muscheler, R., Joos, F., Beer, J., Müller, P. S. A., Vonmoos, M., and Snowball, I.: Solar activity during the last $1000 \mathrm{yr}$ inferred from radionuclide records, Quaternary Sci. Rev., 26, 82-97, 2007.

Naeher, S., Gilli, A., North, R. P., Hamann, Y., Schubert, C. J.: Tracing bottom water oxygenation with sedimentary $\mathrm{Mn} / \mathrm{Fe}$ ratios in Lake Zurich, Switzerland, Chem. Geol., 352, 63-69, 2013.

Navas, A., Soto, J., and López-Martínez, J.: Radionuclides in soils of Byers Peninsula, South Shetland Islands, Western Antarctica, Appl. Radiat. Isotopes, 62, 809-816, 2005.

Navas, A., López-Martínez, J., Casas, J., Machín, J., Durán, J. J., Serrano, E., Cuchi, J. A., and Mink, S.: Soil characteristics on varying lithological substrates in the South Shetland Islands, maritime Antarctica, Geoderma, 144, 123-139, 2008.

Otero, X. L., Fernández, S., de Pablo Hernández, M. A., Nizoli, E. C., and Quesada, A.: Plant communities as a key factor in biogeochemical processes involving micronutrients ( $\mathrm{Fe}, \mathrm{Mn}, \mathrm{Co}$, and $\mathrm{Cu}$ ) in Antarctic soils (Byers Peninsula, maritime Antarctica), Geoderma, 195-196, 145-154, 2013. 
Pallás, R., Smellie, J. L., Casa, J. M., and Calvet, J.: Using thephrochronology to date temperate ice: correlation between ice tephras on Livingston Island and eruptive units on Deception Island vocano (South Shetland Islands, Antarctica), Holocene, 11, 149-160, 2001.

Pienitz, R., Douglas, M. S. V., and Smol, J. P.: Paleolimnological research in polar regions: an introduction, in: Long-term environmental change in Arctic and Antarctic lakes, edited by: Pienitz, R., Douglas, M. S. V, and Smol, J. P., Developments in Paleoenvironmental Research, Springer, 8, 1-17, 2004.

Renberg, I., Bränvall, M.-L., Bindler, R., and Etmeryd, O.: Stable lead isotopes and lakes sediments - a useful combination for the study of atmospheric lead pollutio history, Sci. Total Environ., 292, 45-54, 2002.

Rochera, C., Justel, A., Fernández-Valiente, E., Bañon, M., Rico, E., Toro, M., Camacho, A., and Quesada, A.: Interannual meteorological variability and its effects on a lake from maritime Antarctica, Polar Biol., 33, 1615-1628, 2010.

Rose, N. L., Jones, V. J., Noon, P. E., Hodgson, D. A., Flower, R. J., and Appleby, P. G.: Long-range transport of pollutants to the Falk Islands and Antarctica: evidence from lake sediment fly ash particle records, Environ. Sci. Technol., 46, 9881-9889, 2012.

Sánchez-Hernández, J. C.: Trace element contamination in Antarctica ecosystems, Rev. Environ. Contam. Toxicol., 166, 83-127, 2000.

Santos, I. R., Silva-Filho, E. V., Schaefer, C. E. G. R., AlbuquerqueFilho, M. R., and Campos, L. S.: Heavy metal contamination in coastal sediments and soils near the Brazilian Antarctic station, King George Island, Mar. Pollut. Bull., 50, 185-194, 2006.

Sarkar, A., Singbal, S. Y. S., and Fondekar, S. P.: Pesticed residues in the sediments from the lakes of Schirmacher Oasis, Antarctica, Polar Record, 30, 33-38, 1994.

Sheppard, D. S., Claridge, G. G. C., and Campbell, I. B.: Metal contamination of soils at Scott Base, Antarctica, Appl. Geochem., $15,513-530,2000$.

Shotyk, W., Goodsite, M. E., Roos-Brraclough, F., Frei, R., Henemeier, J., Asmund, G., Lohse, C., and Hansen, T. S.: Anthropogenic contributions to atmospheric $\mathrm{Hg}, \mathrm{Pb}$ and $\mathrm{As}$ accumulation recorded by peat cores from southern Greenland and Denmark dated usig the ${ }^{14} \mathrm{C}$ "bomb pulse curve", Geochim. Cosmochim. Ac., 67, 3991-4011, 2003.

Smol, J. P. and Last, W. M. (Eds).: Tracking environmental changes using lake sediments. Physical and geochemical methods, Developments in Paleoenvironmental Research, Volume 2, Springer, 2001.
Smol, J. P., Birks, H. J., and Last, W. M. (Eds).: Tracking environmental changes using lake sediments. Terrestrial, algal, and siliceous indicators, Developments in Paleoenvironmental Research, Volume 3, Springer, 2001a.

Smol, J. P., Birks, H. J., and Last, W. M. (Eds).: Tracking environmental changes using lake sediments. Zoological indicators, Developments in Paleoenvironmental Research, Volume 4, Springer, 2001b.

Squier, A. H., Hodgson, D. A., and Keely, B. J.: Evidence of late Quaternary environmental change in a continental east Antarctic lake from lacustrine sedimentary pigment distributions, Antarct. Sci., 17, 361-376, 2005.

Sun, L. and Xie, Z.: Changes in lead concentration in Antarctic penguin droppings during the past 3000 years, Environ. Geol., 40, 1205-1208, 2001.

Tin, T., Fleming, Z. L., Hughes, K. A., Ainley, D. G., Convey, P., Moreno, C. A., Pfeiffer, S., Scott, J., and Snape, I.: Impacts of local human activities on the Antarctic environment, Antarct. Sci., 21, 3-33, 2009.

Toro, M., Camacho, A., Rochera, C., Rico, E., Bañón, M., Fernández-Valiente, E., Marco, E., Justel, A., Avendaño, M. C., Ariosa, Y., Vincent, W. F., and Quesada, A.: Limnological characteristics of the freshwater ecosystems of Byers Peninsula, Livingston Island, in maritime Antarctica, Polar Biol., 30, 635-649, 2007.

Toro, M., Granados, I., Pla, S., Giralt, S., Antoniades, D., Galán, L., Martínez Cortizas, A., Soo Lim, H., and Appleby, P. G.: Chronostratigraphy of the sedimentary record of Limnopolar Lake, Byers Peninsula, Livingston Island, Antarctica, Antarct. Res., 25, 198212, 2013.

Velázquez, D., Lezcano, M. A., Frías, A., and Quesada, A.: Ecological relationships and stoichiometry within a Maritime Antarctic watershed, Antarct. Sci., 25, 191-197, 2013.

Webster, J., Webster, K., Nelson, P., and Waterhouse, E.: The behaviour of residual contaminants at a former station site, Antarctica, Environ. Poll., 123, 163-179, 2003.

Webster-Brown, J. G. and Webster, K. S.: Trace metals in cyanobacterial mats, phytoplankton and sediments of the Lake Vanda regions, Antarctica, Antarct. Sci., 19, 311-319, 2007.

Weiss, D., Cheburkin, A., and Shotyk, W.: Determination of $\mathrm{Pb}$ in ashed peat plants using an energy-dispersive miniprobe multielement analyzer (EMMA), Analyst., 123, 2097-2102, 1998.

Yin, X., Liu, X., Sun, L., Zhu, R., Xie, Z., and Wang, Y.: A 1500year record of lead and copper, arsenic, cadmium, zinc level in Antarctic seal hairs and sediments, Sci. Total Environ., 371, 252 257, 2006. 